\title{
A ICONOGRAFIA DE ADÃO, AUTOBIOGRAFIA DO HOMEM MEDIEVAL
}

\author{
Hilário Franco Júnior*
}

RESUMO: Entre os séculos XI e XIII, cresceu muito o número de representações de Adão na Europa Ocidental. Isso era reflexo de um novo interesse dos medievais por si mesmos, o que os levava a verem na história daquele personagem mítico a origem de todas as grandes características físicas, psíquicas e sociais da humanidade. Devido à sua penetração em todos os níveis culturais, a iconografia foi o grande veículo daquela autobiografia coletiva do homem medieval.

ABSTRACT: Between the XI and XIII centuries, the number of representations of Adam increased so much in the occidental Europe. This was a reflex of a new interest of the medievals about themselves that induced them to see in the history of that mythical personage the origin of all great physic, psychic and social characteristics of mankind. Due to its penetration in all cultural levels, the iconography was the vehicle of that collective autobiography of the medieval man.

PALAVRAS-CHAVE: História da Cultura, Europa medieval, imaginário, iconografia adâmica.

KEYWORDS: Cultural History, Medieval Europe, imaginary, adamic iconography.

Apesar de ter sido na Idade Média Central um ponto de encontro privilegiado entre cultura erudita e cultura vulgar, o mito de Adão não se deixa ver com facilidade aos olhos modernos, ainda que suas pegadas estejam um pouco por toda parte no material daquela época que chegou até nós.

$\mathrm{Na}$ teologia, sua revalorização foi clara. Como decorrência da sociedade feudal (que implicara em crescimento demográfico e certa valorização da mulher) e da Reforma Gregoriana (que estimulava

\footnotetext{
* Depto. de História-FFLCH/USP
}

a ação sobre o mundo), desenvolveu-se uma espiritualidade centrada na faceta humana de Deus. A época feudal foi cristológica e cristocêntrica. Os progressos no culto à Virgem, as crescentes representações do Cristo sofredor na Cruz, a atração pelo Jesus menino, testemunham tal espiritualidade. As Cruzadas foram, em certo sentido, a busca deste Deus-homem nos locais onde ele nascera, vivera e morrera. Ora, esse novo interesse pelos homens, pelo Deus feito homem, significava redescobrir a figura do primeiro deles. De fato, perfeito antes do pecado, o Primeiro Homem ressurgiu com Cristo, o "último Adão" (1 Cor 15,45). A partir disso, a conside- 
ração do italiano Pedro Damiano (1007-1072) "tudo o que diz a Lei antiga ou nova, refere-se sem dúvida a Cristo" (PEDRO DAMIANO, 1853, col.1141) - era vista como extensiva a Adão. Das 27 prédicas dos Sermones feriales do francês Jacques de Vitry (1170-1240), doze tratavam da história de Adão (SCHNEYER, 1971, pp.210-212).

Outra prova do revigoramento da figura mítica de Adão está na literatura do período. Sua história foi aproveitada pelo primeiro texto teatral em francês, de meados do século XII, o Jeu d'Adam. A peça destinava-se a um público amplo, colocado diante do pórtico das igrejas, onde era representada. Seu sucesso deveu-se ao fato de colocar a narrativa bíblica no quadro da realidade contemporânea, comentando vários aspectos da sociedade feudal. Em outras obras literárias, Adão não aparecia com o nome e o perfil que a cultura judaico-cristã lhe atribuía, mas revelava-se através da pele de outros personagens míticos. Foi o caso, por exemplo, de Tristão e Merlim. Não se tratava de influência direta, mas de intertextualidade inconsciente, muito freqüente nas relações entre redes míticas de culturas diferentes porém próximas no tempo e no espaço. Por isso o relato adâmico pôde ser inserido na cristianização de outros temas literários célticos, como o do Graal nas primeiras décadas do século XIII (L'estoire del Saint Graal, 1909, pp.124-128).

A antroponímia também registra a revalorização de Adão. Enquanto um estudioso examinando 1800 nomes do clero romano entre princípios do século $\mathrm{V}$ e meados do XI encontrou apenas um indivíduo chamado Adão (LLWELLYN, 1981), nosso levantamento provisório para os séculos XI-XIII a partir de repertórios variados e fragmentários, contabilizou 77 pessoas com aquele nome, todas pertencentes às camadas socialmente superiores. Como a adoção de prenomes seguia o modelo de difusão vertical, com os estratos inferiores adotando o comportamento dos mais elevados (SCHNAPPER, 1984, pp.15-16), pode-se imaginar que muitos indivíduos marginalizados da documentação tenham sido batizados como Adão. A atribuição de prenome, sobretudo em sociedades pré-industriais, expressa fenômenos culturais, sociais e religiosos muito mais do que arbitrariedades de gostos pessoais.

Se a teologia, a literatura e antroponímia sinalizam a nova importância que a Idade Média Central atribuía a Adão, sem dúvida o maior testemunho nesse sentido nos é fornecido pela iconografia. Em números aproximados e redondos, dos primeiros tempos do cristianismo até fins do século XIII, encontramos 2500 imagens, das quais apenas 400, isto é, $16 \%$ do total, produzidas até fins do século X. Das 2100 imagens feitas nos séculos XI, XII e XIII que chegaram até nós, 1400 correspondem aos territórios das atuais Espanha, França e Itália. Nestas regiões - as únicas que serão aqui consideradas - percebe-se claramente a supremacia do século XII, quando foram elaboradas perto da metade das imagens adâmicas do período ${ }^{1}$.

Quanto aos temas, por razões tanto teológicas quanto de sensibilidade coletiva, o Pecado Original era o mais representado, com quase um terço do total. A seguir estavam, pela ordem, as representações visuais da Redenção de Adão, da Expulsão do Para-

1. Esses números, aproximativos e provisórios, foram obtidos a partir do Index of Christian Art de Princeton, da Photothèque do Centre d'Etudes Supérieures de Civilisation Médiévale de Poitiers, da Iconothèque du Groupe Images de l'Ecole des Hautes Etudes en Sciences Sociales de Paris, e do nosso próprio levantamento, ainda em curso. Naturalmente nenhuma listagem desse tipo pode ser considerada definitiva, pois sempre existe a possibilidade de serem descobertas imagens adâmicas até agora desconhecidas, como ocorreu recentemente com os afrescos de Saint-Plancard (Haute-Garonne, 1943), de San Justo (Segóvia, 1962), de SaintEutrope des Salles-Lavauguyon (Haute-Vienne, 1986) e de Cahors (Lot, 1988-1989), ou com os capitéis de Saint-Vincent-de-Paul (Drôme, 1974) e de Saint-Antonin (Tarn-et-Garonne, 1976). 
íso, do Exílio, do Nascimento de Eva, da Criação de Adão, da Estada no Paraíso. Algumas vezes o documento iconográfico mostrava o ciclo completo. $\mathrm{Na}$ maior parte das vezes, representava duas ou mais etapas do mito. Não era incomum que uma mesma cena fosse figurada no mesmo monumento em épocas diferentes. De forma geral, os temas adâmicos acompanharam em cada região aqui considerada, a mesma distribuição proporcional atestada para o conjunto europeu. Não havia uma tendência clara de determinados motivos míticos serem expressados preferencialmente com determinados materiais.

Raramente Adão ou Eva apareciam desvinculados daquela trajetória, pois para o homem medieval tratava-se de um mito, de uma visão globalizadora do mundo, e não de personagens isolados. Ainda assim, algumas vezes Adão foi figurado sem relação com qualquer uma daquelas etapas míticas. Por exemplo, ele está representado como patriarca na Bíblia de Souvigny, como profeta no afresco de Bominaco, como personificação do vício no Speculum virginum de Troyes e na fachada ocidental da catedral de Piacenza, como decoração de maiúscula em uma Bíblia veneziana do século XII, como apóstolo em um relicário do Louvre. Pouco freqüentes, não é fácil interpretar essas representações de Adão isolado da narrativa mítica.

De qualquer forma, como toda iconografia, a dos temas adâmicos resultava de um conjunto de fatores psicológicos, sociais e culturais, cuja base estava presente em toda Cristandade ocidental, e cuja proporção de cada elemento dependia de condições específicas, locais e temporais. Nos relatos visuais de Adão, ao lado dos elementos bíblicos, exegéticos e teológicos, havia muitos provenientes da cultura vulgar. Mesmo as iluminuras bíblicas, de caráter nitidamente clerical, aproveitavam-se em alguns casos de fontes de inspiração não necessariamente eruditas, como por exemplo os textos bíblicos apócrifos. Pelo seu próprio caráter, a linguagem iconográfica utilizava abundantemente os símbolos, cuja polissemia expressava os valores e sentimentos da cultura intermediária, não o dualismo estrito da cultura erudita.

Assim, na tentativa de alcançar o sentido medieval da iconografia adâmica, não podemos nos restringir a buscar uma base textual da imagem plástica. Mesmo que no caso do mito de Adão, os relatos apócrifos tenham tido uma inegável importância. Já se disse com razão, que a iconografia não colocava em imagens os textos apócrifos, mas via neles a possibilidade de preencher lacunas da narrativa bíblica, o que era feito de forma indireta, através de uma série de mediações difíceis de serem atualmente percebidas (ROMANINI, 1991, vol.II, pp.168-169). Tal é o caso de muitas miniaturas nas quais Adão e Eva entravam na ornamentação da letra B do salmo Beatus vir, pois a Glossa ordinaria via uma relação entre o começo daquele salmo e os pais do gênero humano (SMEYERS, 1974, p.52).

Outras vezes, os dados da cultura erudita são insuficientes para a compreensão das imagens. Por exemplo, as representações de Adão e Eva estavam geralmente no lado norte, lugar simbólico do pecado, mas isso não era uma regra. A famosa Eva de Autun foi figurada em uma incomum posição horizontal, devido à liturgia da penitência que se fazia no portal norte da catedral, baseando-se na exegese de uma passagem bíblica (Ez 40,20) feita por Gregório Magno (WERKMEISTER, 1972, p.20). Mas o também célebre Adão da Notre-Dame de Paris, hoje no Museu de Cluny, estava colocado no braço sul do transepto. Ocorre que o contexto histórico era outro - cerca de 130 anos mais tarde - e o contexto iconográfico também, pois no caso parisiense o Primeiro Homem e sua mulher ladeavam uma estátua do Cristo do Juízo Final (ERLANDEBRANDENBURG, 1975).

A criação de Adão, segundo o texto bíblico, deuse no sexto dia, quando Deus modelou o homem a 
partir da argila e insuflou-lhe o sopro de vida "na face" (Gn 2,7). A primeira parte dessa narrativa era menos representada que a segunda, talvez devido a uma certa resistência clerical em mostrar a Divindade praticando uma "arte mecânica", realizando um trabalho manual $^{2}$. Ainda assim, tal concepção estava longe de ser rara, como nos lembra, dentre outros, o relicário de Santo Isidoro, os relevos da fachada de Módena e Compostela e do claustro de Gerona, o afresco de Bagüés (Aragão), os capitéis das igrejas de SaintHilaire-la-Noaille (Aquitânia) e de São Domingos de Soria, as arquivoltas de Chartres e Laon.

A vivificação da nova criatura apresentava maior variedade, sempre explorando o simbolismo das partes do corpo humano tocadas pelo poder divino. Poucas vezes seguia-se literalmente o relato do Genesis, como fizeram as iluminuras da Bíblia de Todi e da Bíblia de Cividale del Friuli ou o mosaico de Monreale. Outras vezes, adaptando a informação do texto bíblico, diferentes partes do rosto humano recebiam o sopro de Deus, caso da boca e das narinas em uma iluminura do Hortus Deliciarum e em um vitral de Chartres; caso da boca, do nariz e dos olhos no afresco de Sant-Sadurni d'Osormort. Outras vezes ainda, interpretava-se "face" somente como "boca", local que parecia mais apropriado para receber o sopro de Deus, caso da miniatura da $B i$ blia do Panteon, dos afrescos de Château-Gontier, de Ferentillo e de San Giovanni a Porta Latina, do mosaico da Capela Palatina de Palermo.

Mais distanciadas da concepção bíblica, porém melhor adaptadas à mentalidade medieval, estavam as imagens nas quais Adão recebe vida através de um toque de Deus. A vivificação à distância, que lem-

2. Mas expressando as transformações sócio-econômicas do século XII, os clérigos itinerantes conhecidos por goliardos falavam no "artífice que criou o homem com argila": Carmina Burana, 224, ed.-trad.P.Rossi, Milão, Bompiani, 1991, p.230. brava a criação dos vegetais e dos animais, era substituída pelo contato direto da mão do Criador com o corpo humano. Reforçava-se assim a idéia do homem centro da Criação, detentor de poder sobre todas as outras criaturas. Ademais, Cristo investira os apóstolos colocando sua mão sobre eles, e a partir disso a condição sacerdotal era transmitida pela imposição da mão. O primeiro gesto do ritual de vassalagem era a colocação das mãos do futuro vassalo entre as do futuro senhor. Gesto de enorme importância, transferido por isso à postura do orante: a plurimilenar posição de rezar em pé com os braços erguidos e mãos espalmadas, cedeu lugar à oração ajoelhada e com as mãos juntas.

Esse caráter mágico das mãos como transmissoras de vida e poder, é que explica o Adão da fachada norte (hoje no lado oposto) da catedral de Compostela, que se torna um ser animado graças à mão de Deus espalmada sobre seu coração. Conhece-se mesmo um caso, igualmente do século XII capitel do claustro do mosteiro de São Domingos, em Perelada - no qual na cena do nascimento de Eva, Deus coloca a mão sobre o coração da mulher. Em uma escultura do século seguinte, na fachada ocidental da catedral Saint-Étienne, em Auxerre, Adão foi vivificado também daquela forma. Nas cenas em que Deus modela o homem pela cabeça (como em Módena e Auxerre), parece que o mesmo gesto era o responsável pela transmissão de vida a ele. Devese ainda lembrar de um caso único, num capitel do claustro de Santa Maria de Alquézar, em Aragão, no qual o gesto divino é exercido sobre o ouvido de Adão (FRANCO JUNIOR, 1996c).

Seja no coração, na cabeça ou no ouvido, é sempre a mão direita de Deus que realiza o ato. O simbolismo positivo do lado direito era um dado cultural muito difundido. Ele aparece inúmeras vezes na Bíblia. Para alguns comentários rabínicos, o primeiro ser humano, andrógino, era masculino do lado direito e feminino do esquerdo. Os romanos 
acreditavam que a formação de um feto masculino ocorria quando o esperma saído do testículo direito do pai se instalava no lado direito do útero materno. A preeminência do lado direito expressava uma hierarquização social, sexual, profissional e etária, fundamental para as sociedades arcaicas; em suma, a direita é o sagrado, a esquerda o profano (HERTZ, 1970).

Quanto à posição do corpo humano durante o processo de criação, as imagens apresentam as mais diversas soluções. Em um extremo estava a rigidez total daquela estátua de argila, deitada antes de receber o toque vivificador, como aparece no capitel de Alquézar. Em uma postura intermediária, o Primeiro Homem ainda está deitado no solo, mas já com uma perna flexionada e os braços erguidos, caso por exemplo do afresco de Château-Gontier. Ou ele se encontra sentado, com o Criador moldando sua coxa (Bible de Cîteaux, 1109, fol.76). Em outro extremo, apesar de ainda inanimado, Adão já é representado em pé, na postura vertical que o diferenciaria dos outros animais. Este esquema é o mais comum, com exemplos tanto do século XI (Bíblia de Rodas e afresco de Bagüés) quanto do século XII (Hortus Deliciarum, Breviário de Limoges, relevo de Compostela, capitel de Saint-Antonin) e do XIII (mosaico de São Marcos de Veneza, relevo de Amiens).

Os séculos XI e XII tendiam a mostrar Adão com o corpo já inteiramente esculpido. A única exceção que conhecemos, do último quarto do século XII, é um belo capitel da galeria sul do claustro da catedral de Sainte-Eulalie de Elne (Pyrenées Orientales): Adão, de corpo ainda pequeno, encontra-se mergulhado até aos joelhos na argila da qual está sendo moldado (Fig.1). O século XIII, por sua vez, não tinha pudor em mostrar Adão incompleto, como um feto em processo de formação. Um bom exemplo é um medalhão do portal superior da Sainte-Chapelle de Paris: Deus está em pleno trabalho de modelagem, e Adão da cintura para baixo encontra-se ainda fun- dido com a terra. Concepção semelhante aparece em um vitral da catedral de Bourges.

O segundo momento do mito - o nascimento de Eva - teve na iconografia medieval duas fases claramente marcadas. Até meados do século XI, era comum a cena que mostrava Deus modelando Eva a partir da costela extraída de Adão. Essas duas etapas apareceram pela primeira vez fundidas numa só, na porta da catedral alemã de Augsburgo. Desde então o tema e o esquema se difundiram: "a criação tornou-se uma procriação e Deus delega a Adão sua própria função" (ZAPPERI, 1983, p.21). Relacionada com essa idéia-imagem, desenvolveu-se outra, que via na origem da Igreja o sangue e a água que jorraram do corpo do Cristo crucificado quando a lança do legionário romano perfurou-o no lado direito. Assim como Eva nascera da costela de Adão, a Igreja, inversão de Eva, nascia da costela do "segundo Adão", redentor do primeiro.

A melhor expressão iconográfica dessa associação é uma iluminura bíblica de meados do século XIII. Ali, na mesma cena, reúnem-se momentos da história sagrada cronologicamente separados, porém atemporalmente contemporâneos. Na parte baixa da imagem, Eva sai do lado esquerdo de Adão, que se encontra deitado com as pernas ligeiramente cruzadas, gesto simbolizador de contato com o mundo divino. Deus com a mão esquerda toca a mão direita de Eva. No centro da cena, o Cristo crucificado tem seus pés quase encostados na nuca e no ombro do Adão adormecido, de forma semelhante às imagens que mostravam o Primeiro Homem sepultado sob a Cruz e sendo perdoado e ressuscitado pelo sangue divino que escorria sobre ele. Ao mesmo tempo, do lado direito de Cristo nasce - também da altura da bacia, como ocorrera com Eva em relação a Adão - a Igreja, já coroada (Bible moralisée, ca.1230-1250, fol.186).

Tanto as imagens de Eva nascendo diretamente de Adão como em um parto, quanto as da Igreja 
nascendo de Cristo, tinham conteúdo ideológico. Elas estavam ligadas à Reforma Gregoriana e sua meta de purificar a Igreja, afastando-a das ingerências laicas e separando nitidamente a sociedade cristã em clérigos e leigos. Passo fundamental nessa direção, era regulamentar a reprodução biológica, e por decorrência social, da Cristandade: aos clérigos foi imposto o celibato obrigatório, aos leigos o matrimônio, tornado sacramento. Diante disso, ao mesmo tempo em que se continuava a buscar esposas geograficamente próximas para consolidar os senhorios, passava-se a procurá-las genealogicamente distantes o bastante para evitar o incesto.

Situação difícil, que no século XII colocou a mulher no centro das questões sociais, tornando-a por isso mais respeitada (como mostram o culto à Virgem e o amor cortesão) e ao mesmo tempo mais detestada (como revela o crescimento da misoginia). Nesse quadro, o nascimento de Eva do flanco do marido servia para comprovar sua inferioridade e dependência, paralelas às de todo ser humano em relação ao Criador. Mas, por outro lado, estabelecia certa igualdade com o homem, pois ela não fora formada de uma parte inferior do corpo dele, mas de seu peito. A mesma relação simbólica aplicava-se à Igreja em relação a Deus. Disso decorria o domínio do homem sobre a mulher, e da sociedade eclesiástica sobre a sociedade laica. Esse complexo quadro sócio-teológico cruzava-se muitas vezes com elementos folclóricos, gerando cenas ricas e interessantes, como a da Eva barbada de Saint-Savin (FRANCO JUNIOR, 1996b).

Devido à estreita vinculação do esquema iconográfico do nascimento de Eva com a Reforma Gre-

3. Tal foi o caso da Bíblia de Cividale del Friuli (ca.1120), da Bíblia de Todi (ca.1125), da Bíblia do Panteon (ca.1130), da Bíblia de Florença (ca.1140). Aquela imagem era ainda acessível ao público laico em catedrais como de Módena (fachada ocidental) ou Salerno (frontal de marfim do altar), igrejas urba- goriana, não é de se estranhar que ele tenha sido utilizado sobretudo no século XII e em iluminuras bíblicas, especialmente da Itália norte-central ${ }^{3}$. Mas se havia certa predominância italiana no uso daquele esquema, ele estava longe de ser raro nas outras regiões. Ele aparece por exemplo em Castela (São Domingos de Soria), Aragão (Sigena), Catalunha (Gerona, Estany), Auvergne (Bíblia de Souvigny), Ile-de-France (Sainte-Geneviève de Paris), Picardia (Bíblia de Amiens, Bíblia de Corbie), Alsácia (Andlau), Savóia (Aimé). Tampouco era exclusividade do século XII, pois estava presente também no XIII no Saltério de São Luís e nas grandes catedrais góticas: vitrais de Chartres, Le Mans e Bourges, relevos da fachada ocidental de Amiens, Auxerre, Bourges e Notre-Dame de Paris, relevo do lado norte de Reims, medalhão exterior da Sainte-Chapelle.

A etapa seguinte do mito é a menos documentada pela iconografia, apesar de paradoxalmente ter estimulado muito a imaginação medieval. Trata-se do período de permanência dos primi parentes no Paraíso terrestre. O texto bíblico fornece muito poucas informações a respeito. O capítulo 2 do Genesis fala apenas no Senhor colocando Adão naquele local, e depois criando os animais e a seguir Eva para lhe fazerem companhia. O capítulo 3 narra a tentação, o pecado e a expulsão, também sem dar detalhes sobre a vida dos primeiros humanos no Éden. Estranhamente, os vários apócrifos sobre os pais do gênero humano não focalizam aquele período de felicidade, e sim a vida deles no exílio. Apenas um apócrifo quantifica a estada no Éden, sete anos e dois meses (Giubilei, 1987, p.230).

nas como San Giovanni a Porta Latina (afresco da abóbada) ou São Zeno de Verona (tanto na porta de bronze quanto na fachada), igrejas rurais como Santa Maria ad Cryptas (Fossa, Abruzzos) ou San Pietro in Valle (Ferentillo, Umbria) com seus afrescos. 
Para a tradição rabínica, por sua vez, ela teria sido de oito horas: na quarta hora do dia Adão recebeu alma, na sétima foi-lhe dado Eva, na oitava receberam a interdição, na nona fizeram amor, na décima cometeram o pecado, na décima-segunda foram expulsos (Los capítulos de Rabbí Eliezer, 1984, pp.109-110). De forma geral, também para os cristãos o tempo de Adão e Eva no Paraíso foi curto, ainda que os comentadores bíblicos discordassem quanto à sua duração. Para um texto muito popular, que em meados do século XII resumia o essencial das crenças coletivas ocidentais, Adão foi criado na terceira hora, Eva na sexta e foram expulsos após a nona, isto é, viveram sete horas no Paraíso (HONORIO AUGUSTODUNENSIS, 1854, col.1119 C). Para a Legenda Aurea, que registrava aquelas crenças em meados do século XIII, Adão pecou na sexta hora, sendo logo expulso (JACOPO DE VARAZZE, 1969, p.229). Poucas décadas depois, também a Divina Commedia estimava em sete horas a estada no Éden (DANTE ALIGHIERI, 1979, Paradiso XXVI,139-142).

A descrição bíblica do Paraíso era sucinta demais para o gosto medieval, limitando-se a falar em árvores bonitas e de frutos saborosos e no rio que por ali passava antes de se dividir em quatro e irrigar as terras fora do Éden (Gn 2,9-10). Tentando desenvolver e aprofundar aqueles poucos dados, a cultura erudita elaborou muitos comentários sobre o Paraíso (GRIMM, 1977), enquanto a cultura vulgar o fazia a partir de mitos e tradições de diferentes origens. Mas, curiosamente, a iconografia pouco representou o espaço edênico. Alguns mapas mostram-no com uma pequena imagem de Adão e Eva para facilitar sua localização e identificação (Beatus de SaintSever, ca. 1028-1072, fol.45 ter). Alguns capitéis representam alegoricamente os quatro rios, como em Cluny e Vézelay.

No museu de Saint-Antonin, um capitel da igreja local (Tarn-et-Garonne) mostra o primeiro casal pitorescamente sentado no Paraíso, ele sobre uma cadeira curul, símbolo de poder, ela sobre um simples banquinho. Entrevê-se ainda a paisagem paradisíaca na cena de atribuição de nomes aos animais, como nas iluminuras de alguns bestiários e do Hortus Deliciarum, em um mosaico de São Marcos de Veneza e na tapeçaria de Gerona (FRANCO JUNIOR, 1996d). Essa relativa carência talvez pretendesse evitar especulações sobre temas delicados, caso da primeira relação sexual entre Adão e Eva ${ }^{4}$. Ou caso do mito judaico de Lilith, que teria sido a primeira esposa de Adão, repudiada justamente porque pretendia ficar sobre o marido durante o ato sexual. Ou, pior ainda, caso da suposta bestialidade de Adão, que teria se unido fisicamente a animais antes de ter uma companheira "osso dos meus ossos, carne da minha carne" (Gn 2,23).

A etapa do mito que mereceu maior atenção da Idade Média, foi sem dúvida a do Pecado Original. Tanto no período anterior ao ano mil, quanto nos séculos XI-XIII, tal episódio representou quase um terço do total das imagens adâmicas. De um lado, porque os medievais viam nele o ponto de partida de todas as limitações e fraquezas humanas, físicas e morais. De outro, porque ele explicava e justificava o ponto de vista erudito sobre um importante dado sociológico e cultural, a inferioridade da mulher, que fora enganada pela serpente (Gn 3,1-6; 1 Tm 2,14). Contudo esse papel de pecadora não deixava de ser afetado pela revalorização social feminina. E às vezes de forma curiosa, minimizando a culpa da

4. Para AGOSTINHO, De Genesi ad litteram, IX,11,19, ed.trad.B. Martin, Madrid, BAC, 1969, p.832-833, no Paraíso o ser humano não procriaria de forma pecaminosa. Mas a partir de comentários talmúdicos - como o Midrach Rabba. Genèse, 22,2, trad.B. Maruani e A.Cohen-Arazi, Paris, Verdier, 1987, p.246, e Los capítulos de Rabbí Eliezer, XI,2, p.110 - muitos cristãos pensavam de forma diferente. 
mulher ao ressaltar seu caráter inconseqüente. Ela tornava-se uma pecadora quase sem o querer, e mesmo sem o saber: um capitel de Vézelay coloca Eva de costas para a Árvore, de forma que sem olhar para o fruto, ela o colhe com uma mão e com outra entrega-o a Adão; na Tapeçaria da Criação da catedral de Gerona, ela é uma pecadora instintiva, que mesmo antes de estar completamente formada, ainda presa ao flanco de Adão, estica os braços em direção à Árvore da Vida, mas já olha mais adiante para a Árvore Proibida!

As imagens sobre o Pecado Original seguiam na sua estrutura básica o relato bíblico. Os comentários exegéticos e as tradições orais forneciam os detalhes nos quais aquele texto era omisso, permitindo interessantes variações. Por exemplo, a serpente está quase sempre voltada para Eva, entregando-lhe o fruto ou simplesmente assistindo ao desenrolar da cena. Em algumas iluminuras góticas, a serpente tem rosto feminino, criando um jogo de espelho entre ela e Eva. Mas em um capitel do século XII, do mosteiro catalão de San Pedro de Rodas (hoje no Museu de Cluny), a serpente aparece virada para Adão. O mesmo ocorre na arquivolta do portal ocidental da igreja de Saint-Martin de Besse, no Périgord. Mais interessante, num relevo de Guarbecque (Pas-deCalais) (Fig.2) e num capitel de Mauriac (Gironda), Adão e Eva estão lado a lado e seguram juntos a mesma fruta. Atribuição diferente da responsabilidade, ou mera inovação plástica?

O mais comum era acentuar a culpabilidade de Eva. Muitas vezes isso era feito pela localização dos personagens na cena. Uma das possibilidades, era

5. Esta foi a concepção adotada, por exemplo, na Espanha pelo relicário de Santo Isidoro, pelos capitéis de Alquézar e de Porqueras e pelo afresco de Sant-Sadurni, na França pelos capitéis de Saint-Martin d'Ainay e Targon, pelos lintéis de Andlau e de Neuilly-en-Donjon, pelas miniaturas do Beatus de Saint-Sever e colocar os primi parentes do mesmo lado da Árvore: nesses casos Eva está sempre mais próxima a ela, o que porém não exime totalmente o homem daquele ato ${ }^{5}$. Outro arranjo da cena, mais difundido e um pouco mais igualitário, punha a Árvore separando o casal: de um lado Eva, próxima à serpente e com o fruto na mão, de outro Adão, afastado e passivo. A participação do homem no Pecado é denunciada apenas pelo fruto na mão. Parece faltar convicção a essa adesão, e logo após ter cometido a falta, Adão expressa sua dor e arrependimento através de um gesto típico da cultura folclórica, que contrabalançava o tratamento erudito do tema. Colocando a mão sobre a garganta, ele indica que o fruto ficou ali metaforicamente entalado, tornando-se parte de seu corpo - o pomo de Adão - destinada a impedir que a falta cometida fosse esquecida por ele e seus descendentes. Gesto ontológico de uma particularidade da fisiologia masculina, ele foi aplicado a Eva umas poucas vezes: ela e o marido tem a mão na garganta em um capitel da porta norte de Santa Maria del Pino, em uma arquivolta do portal oeste de Santa Maria de Covet (ambas na Catalunha) e também em SaintMartin de Besse.

O Adão engasgado pelo pecado aparece algumas vezes em representações do século XI (capitéis de San Martin de Frómista, em Castela, e de Cluny) e do XIII (vitrais de Chartres, Tours e Le Mans, relevos de Auxerre e Amiens, afresco de Sant-Paul de Casserres, na Catalunha). No entanto foi no século XII que aquela imagem ganhou destaque na iconografia adâmica. Curiosamente, por razões que não nos estão claras, na Itália essa metáfora do Pecado foi rara. Ela está pre-

da Bíblia de Amiens, na Itália pelo relevo da porta de bronze de Pisa, por um marfim do Museu de Salerno, pelo mapa-mundi de Turim (hoje na Biblioteca Nacional de Paris), pelo Exultet de Monte Cassino (hoje em Londres), pelos relevos das catedrais de Módena e de Cremona. 
sente apenas, que saibamos, em uma escultura lombarda do século XI (púlpito de Santo Ambrogio de Milão), em um capitel do século XII do claustro da catedral de Aosta (hoje no museu de Turim), em uma miniatura toscana do século XIII (Exultet do Museu del Duomo de Pisa) e em fins do mesmo século em um relevo marquesano (fachada do Palazzo Comunale de Ancona). Por outro lado, ela é bastante freqüente nas demais regiões ${ }^{6}$.

Em pelo menos um caso, um fato importante da história recente foi associado ao gesto adâmico: um capitel do claustro de San Juan de la Peña. Como se sabe, foi ali que pela primeira vez, em 1071, a liturgia romana substituiu a hispânica, introduzindo a Reforma Gregoriana na Península Ibérica e gerando forte reação antes de se impor décadas depois. A principal diferença entre as duas liturgias, é o fato da hóstia ser dividida em sete, oito ou nove partes no rito visigótico-moçárabe e em três no galicanoromano. Ora, o Adão representado no mosteiro aragonês em meados do século XII, coloca a mão na garganta de uma forma especial, com apenas três dedos (os dois menores aparecem dobrados). Ainda que de significado discutível, tal particularidade, única na iconografia adâmica, sem dúvida deveria remeter os observadores medievais à questão da prática ritual (Fig.3).

Sob a ótica folclórica, a imagem da Árvore entre Adão e Eva lembrava a ruptura da unidade inicial, existente ao menos no plano psicológico, e que

6. Ela é atestada, para dar apenas um exemplo de cada local, nas Astúrias (capitel de San Juan de Amandi), em León (relevo de San Pedro de Cervatos), Castela (Bíblia de Burgos), Aragão (capitel de San Juan de la Peña), Catalunha (pintura sobre madeira de Sagàs), Languedoc (capitel de Saint-Michel de Lescure), Aquitânia (friso de Saint-Pierre de Loupiac), Poitou (capitel de Airvault), Ile-de-France (capitel de Deuil), Borgonha (tímpano de Anzy-le-Duc), Auvergne (capitel de Bozouls), Provença (capitel Notre-Dame de Embrun), Rhône-Alpes (Saint-Restitut). era rompida exatamente pela Árvore, isto é, pelo conhecimento que revelava a presença de traços contraditórios naquele ser andrógino, traços específicos a cada uma de suas metades. De fato, "Deus criou o homem à sua imagem: à imagem de Deus o criou, macho e fêmea os criou" (Gn 1,27). Tudo estava contido naquele ser completo, microcósmico. Tirar Eva da costela de Adão tinha sido uma cirurgia de separação, pois eles eram formados dos mesmos ossos, eram "dois em uma só carne" (Gn 2,2324). Ao pecar, eles tomaram consciência daquela divisão, da qual o sexo era apenas a prova visível: sexus vem de sectio ("corte", "separação"), termo derivado de secare, "cortar", que na Idade Média ganha uma acepção específica, sexual, "castrar" 7 .

Como a origem do autoconhecimento, e portanto a expulsão do Paraíso, estava no fruto proibido, especulou-se muito sobre sua exata natureza. A iconografia não ficava obviamente imune a isso. Muitas vezes representava um fruto indefinido, como faz o texto bíblico (Gn 3,6). Algumas vezes essa indefinição levava a uma mistura de características: na escultura da catedral de Gerona, as folhas da Árvore Proibida são de figueira mas o fruto é a uva; a Eva de Autun tem sua nudez coberta por folhas de uva, embora colha uma maçã. Mais comumente, a iconografia cumpria seu papel exegético e propunha uma solução ao enigma. Em

7. DU CANGE, C.F. Glossarium Mediae et Infimae Latinitatis. ed.L.Favre, Paris, Librairie des Sciences et des Arts, reed. 1938, vol.V, p.146. No latim clássico o grupo verbal secare não tinha nenhum sentido de "sexo": ERNOUT, A. e A.MEILLET, Dictionnaire étymologique de la langue latine. Paris, Klincksieck, $4^{a}$ ed. 1979, p.622. Para a amputação de orgãos genitais, falavase em castrare (ou ainda, sem serem específicos, em subducere, exsecare ou excidere), mas no latim cristão sectus, particípio passado de secare, ganhava o sentido de "eunuco", "castrado", cf. BLAISE, A. Dictionnaire latin-français des auteurs chrétiens. Estrasburgo, Le latin chrétien, 1954, p.747. 
função do simbolismo de certas frutas e de dados culturais locais, hesitava-se principalmente entre o figo, a uva e a maçã (FRANCO JUNIOR, 1992, pp.89-91).

O primeiro aparece mais na Espanha (Bíblia de San Pedro de Rodas, afrescos de Maderuelo e Sagàs) e Itália (mosaicos de Otranto, Palermo e São Marcos de Veneza, relevo e porta de São Zeno de Verona), do que na França (capitel de Lavaudieu). Inversamente, a uva não foi representada como fruto proibido na Itália, pouco aparece nesse papel na Espanha (claustro de Gerona), tem vários exemplos na França (Deuil, Notre-Dame-du-Port, Saint-Germain-desPrès, Vézelay). A maçã por sua presença mais ou menos difundida em toda Europa ocidental, por seu antigo simbolismo celta de fruta do conhecimento e por sua associação ao coração devido à forma e à cor vermelha, era a mais utilizada pela iconografia como sendo o fruto proibido. A longa lista destas imagens cobre os três séculos da Idade Média Central e os três países aqui considerados ${ }^{8}$.

A indecisão quanto à fruta revela interessantes dados sócio-econômico-culturais, como se pode ver no caso de Vézelay. Há ali dois capitéis da nave sobre o Pecado Original. No mais antigo, do século XI, Adão e Eva comem uvas, enquanto naquele esculpido no segundo quarto do século XII, depois do incêndio que destruiu grande parte da basílica, o fruto pecaminoso passa a ser a maçã. Essa mudança atesta uma evolução no simbolismo do fruto, provavelmente relacionada à crescente valorização da

8. Nela estão, por exemplo, Avilés, Covet, Estany, Estibaliz, Loarre, Porqueras, San Martin de Frómista, San Pablo del Campo, Sant-Pau de Casserres, Airvault, Andlau, Angers, Aulnay, Biblia de Corbie, Biblia de Souvigny, Bourges, Cahors, Chartres, Cluny, Nîmes, Notre-Dame de Chauvigny, Saint-Benoît-sur-Loire, Tavant, Verdun, Vézelay, Biblia Pauperum, Módena, Sant'Angelo in Formis, Parma, Salerno, São Zeno de Verona. eucaristia e às novas condições agrícolas do século XII: a importância que a uva passava a ter naquele momento para o cristianismo e para a Borgonha, não se coadunava com o caráter negativo do fruto proibido bíblico.

Comido o fruto, qualquer que tenha sido ele, chegou-se à quinta etapa do mito de Adão, a Expulsão. Pelo relato bíblico, o próprio Deus expulsou os primeiros humanos do Éden, colocando diante do jardim um querubim com espada fulgurante para impedi-los de voltar (Gn 3,23-24). Todavia a representação iconográfica dessa cena, atribuía às vezes ao anjo a tarefa de colocar Adão e Eva para fora do Paraíso. Tal ocorria em especial nas regiões italianas $^{9}$ : Veneto (porta de bronze e fachada de São Zeno de Verona), Lombardia (fachada de Cremona), Emilia-Romagna (fachada de Módena), Toscana (Biblia de Florença, porta da catedral de Pisa), Umbria (Biblia de Todi, relevo da Fontana Maggiore de Perúgia, afresco de Assis), Lazio (Biblia do Panteon, afresco de San Giovanni a Porta Latina), Campânia (afresco de Sant'Angelo in Formis, marfim de Salerno), Puglia (porta de bronze do Monte Sant'Angelo, mosaico de Otranto), Sicília (mosaicos de Monreale e de Palermo).

O sentido disso estava provavelmente ligado a duas razões, uma formal, outra espiritual. A primeira respondia a um fenômeno comum na arte da época, o de fundir em uma só cena dois momentos da narrativa mítica. Foi o que vimos no caso da formação de Eva, em que a retirada da costela de Adão e

9. Nos outros locais tal concepção era bem menos comum, ainda que presente: na Espanha, capitel de São Domingos de Soria, afrescos de Sant-Marti Sescorts e de Sigena, iluminura da Biblia de Rodas; na França, capitéis de Étampes, Saint-Sernin de Toulouse e Sainte-Geneviève de Paris, vitrais de Le Mans e Sens, relevos das catedrais de Nîmes, Auxerre, Bourges, Chartres e Paris, além da Sainte-Chapelle. 
a moldagem da mulher nessa costela tornaram-se uma única coisa, a mulher nascendo do flanco de Adão. A outra razão era evitar que a concepção mais humanizada e suavizada que então se desenvolvia sobre a Divindade, fosse afetada pela atitude repressora da Expulsão. Nessa linha, algumas imagens relacionavam o castigo imposto pelo Deus Pai ao perdão anunciado pela Natividade do Deus Filho. Em uma imagem da porta da catedral de Pisa, a Eva que sai do Paraíso parece penetrar na cena acima, na qual os Magos vão adorar o Menino.

Quase sempre o Paraíso do qual os primeiros humanos foram arrancados pelo Pecado, era figurado com características urbanas. Algumas vezes, como no afresco de Sant-Sadurni d'Osormort (Catalunha), o Adão recém-criado é introduzido por Deus no Paraíso através de uma estreita porta aberta nas muralhas que o cercavam. Apesar do Genesis falar em "jardim" do Éden, sem lhe atribuir traços urbanos (Gn 2,8), a Idade Média tendia a ver o Paraíso terrestre com as características da Jerusalém celeste descrita no Apocalipse. Ou ainda como o hortus conclusus, o "jardim fechado" do Cântico dos Cânticos (Ct 4,12), modelo do Paraíso simbólico que era o claustro monástico. Ademais, o contexto histórico da Idade Média Central favorecia essa urbanização da idéia de Paraíso, pois as cidades eram então as grandes promotoras das transformações sociais, e surgiam por toda parte.

A iconografia sobre a Expulsão insiste ainda sobre três outros elementos. O primeiro deles é psicológico, a tristeza que atinge os humanos diante da perspectiva de viverem fora do Éden. Sentimento que não decorria das dificuldades materiais que teriam, e que eles ainda não podiam avaliar. Tratavase, e isso já estava ao alcance de sua percepção, de se afastar da beatitude divina. Daí o semblante triste que Adão e Eva exibem logo após o Pecado. O melhor exemplo desse estado de espírito, talvez apa- reça em uma iluminura italiana: a cena da Expulsão mostra Adão com feições envelhecidas e barbado, claramente diferente do homem de rosto quase infantil e imberbe da cena anterior (Biblia Pauperum, ca.1250, fols.1v-2r).

Os dois outros aspectos insistentemente mostrados pela iconografia da Expulsão são de ordem material: a roupa e o instrumento agrícola recebidos pelos humanos para enfrentarem os rigores do mundo além-muralhas. O primeiro objeto é explicitado pelo texto bíblico, que o define como "túnicas de pele" entregues por Deus a Adão e sua mulher (Gn $3,21)$. Destinadas à primeira vista a proteger os corpos, tais vestes eram freqüentemente representadas muito curtas, mal ocultando a nudez, como se a iconografia preferisse enfatizar a função moral das roupas. Além disso, ao deixar descobertos os seios de Eva, insistia-se na questão da maternidade, central para a humanidade pós-edênica. Quanto ao segundo objeto, ele não aparece no relato bíblico. Mas como esse fala na necessidade de Adão "trabalhar a terra" (Gn 3,23), era natural que a sociedade agrícola medieval imaginasse o Primeiro Homem deixando o Éden com uma ferramenta nas mãos.

Chegava-se assim à etapa seguinte do mito: o Exílio. De fato, a vida dos primi parentes fora do Paraíso girou em torno da procriação, do fratricídio e, articulando esses elementos, do trabalho. Parte central do castigo divino à mulher foi condená-la a parir com dores $(\mathrm{Gn} 3,16)$, e inúmeras imagens referem-se ao fato ao mostrarem Eva amamentando. Devido ao caráter punitivo da maternidade, pouco se representava Eva com os filhos, em cena de aconchego familiar, como aparece no afresco de Sigena e no relevo da catedral de Ferrara (hoje no museu local). Geralmente tendo como fundo uma paisagem hostil e desoladora, Eva amamenta enquanto Adão trabalha a terra, tentando arrancar dela "o pão com o suor do rosto" (Gn 3,19). Outras vezes perto do Adão agricultor, aparecia Eva fiando, atividade que 
não se baseava em texto bíblico, canônico ou apócrifo, e sim na realidade sócio-econômica da época produtora das imagens. Apesar da mulher medieval não ter sido totalmente poupada das tarefas agrícolas, Eva raramente era representada naquela atividade. As exceções ficam por conta de um relevo da fachada ocidental do Duomo de Módena, de um marfim da catedral de Salerno e de um afresco de Sant-Marti de Brull (Catalunha).

Refletindo essa realidade, a iconografia destacava o trabalho agrícola. De um lado, porque ele foi a atividade básica da economia ocidental pelo menos até princípios do século XIX. De outro porque, excetuadas as grandes cidades italianas no século XIII, o trabalho têxtil era basicamente feminino. Por isso mesmo quase não há referências à origem da fiadeira, instrumento emblemático de Eva, ainda que ela já o carregue ao deixar o Paraíso, segundo o mosaico de São Marcos. Por outro lado, representava-se com freqüência Adão saindo do Paraíso com uma enxada sobre o ombro. Essa origem divina da principal ferramenta de trabalho do homem foi mesmo explicitada em certas imagens: na porta de bronze de Monreale um anjo en-trega a enxada a Adão; em um medalhão da Sainte-Chapelle a própria Divindade é que faz isso. Há pelo menos um caso- um afresco de Sigena - no qual um anjo ensina a Adão como manejar aquele instrumento.

Havia sem dúvida por detrás disso uma revalorização ética do trabalho, que nos séculos XII e XIII deixava de ser visto pela teologia apenas como um castigo pelo Pecado Original. Destacava-se o fato de que Adão logo após sua criação fora colocado no "Éden para o cultivar e guardar" (Gn 2,15), e que assim a punição decorrente da Expulsão não tinha sido exatamente o trabalho em si, mas uma natureza hostil que pedia um esforço contínuo, árduo e pouco produtivo. Insistia-se que Deus tinha sido o primeiro artesão, o summus artifex, e as catedrais góticas representavam com frequiência cenas do trabalho cotidia- no de corporações de ofício. Não é de se estranhar, portanto, que o vitral de Chartres que trata do trabalho de Adão esteja significativamente posicionado logo abaixo e à direita do Cristo em majestade.

Embora amenizado e reinterpretado, o sentido penitencial do trabalho não desapareceu. Continuouse por toda Idade Média Central a se relacionar labor, sudor e dolor. Um ponto importante dessa associação, era estabelecido por outro evento mítico dentro daquela mesma sexta etapa narrativa, o fratricídio cometido por Caim. Como o Genesis não dá detalhes sobre o evento, a partir do fato de Caim ter sido agricultor ( $\mathrm{Gn} 4,3)$, a iconografia medieval imaginou muitas vezes um instrumento agrícola como a arma do crime, caso por exemplo do mosaico da Capela Palatina de Palermo. Ao sangue menstrual que Eva derramava fora do Paraíso (Los capítulos de Rabbi Eliezer, 1984, p.126) misturava-se o sangue de seu filho, confirmando e aumentando a maldição que pesava sobre a terra, tornando mais difícil tirar dela o sustento necessário.

Desta forma alcançava-se a sétima e última etapa do mito, centrada no problema da morte e ressurreição de Adão. Quando Deus advertira o homem para não comer do fruto proibido, explicara que se ele o fizesse morreria (Gn 2,17). Porém, observa Anselmo de Canterbury, não era possível que Deus excluísse da Salvação os protoplastas, de quem descendem todos os humanos que terão acesso à cidade celeste (ANSELMO, 1963, p.416). E de fato, quando da morte de Adão o Criador acenou com a ressurreição, afirmando que no devido tempo o Primeiro Homem "se sentará no trono daquele que o suplantou" (Vita Adae, 1929, p.143). Reforçou essa esperança o fato de Jesus ter nascido no mesmo lugar em que Adão fora criado (Vita Adae, 1929, p.147). Depois a Crucificação se deu no mesmo local em que Adão fora sepultado, de forma que o sangue de Cristo lavou definitivamente o pecado do Primeiro Homem. 
Graças a isso abriu-se a possibilidade da ressurreição de todos os humanos, pois "assim como em Adão todos morrem, em Cristo todos reviverão" (1 Cor 15,22; Mt 27,52). Por isso já nas catacumbas e nos sarcófagos cristãos primitivos, as cenas de Adão eram contrapostas às de Cristo, lembrando que a culpa do primeiro tornava necessária a redenção do segundo. Pelo mesmo motivo, em várias catedrais góticas francesas as cenas do Pecado e da Expulsão formam a base do trumeau no portal dedicado a Maria, através de quem Deus se encarnou para resgatar a falta de Adão. Assim como Cristo era o novo Adão, Maria era a nova Eva (FRANCO JUNIOR, 1996a). Cristo desceu ao Limbo e resgatou Adão e Eva, que $\mathrm{O}$ beijaram emocionados reconhecendo que estas são "as mãos que me formaram" (Atti di Pilato, 1981, p.286): a morte gerada pelo Pecado do homem era vencida pela morte de Deus.

Daí a frequiência com a qual a iconografia recorria àquele apócrifo. Apenas dois aspectos podiam diferir na sua representação visual. Primeiro, o episódio estar colocado cronologicamente entre a Crucificação e a Ressurreição do Senhor, ou, mais comum em fins da Idade Média, dentre as cenas da Glorificação. Segundo, o fato de Adão e Eva aparecerem vestidos nas figurações que seguiam a tradição plástica bizantina (como no Exultet de Bari, em um quadro do Maestro della Croce, em uma escultura de Guido de Como, no capitel de SaintVincent-de-Paul, em Valence) ou nus conforme a tradição ocidental (porta de Verona, afresco de Sant'Angelo in Formis, afresco de Tavant, miniatura do Saltério de São Luís).

O tema correlato de Adão enterrado sob a Cruz foi muito popular, também baseado em textos apócrifos. Pelo menos desde o século VIII, havia no monte Calvário uma capela dedicada a Adão, no local em que se acreditava ter ocorrido a Crucificação, o que impressionava os peregrinos ocidentais que para ali se dirigiam. Isso talvez tenha contribuído para que o tema surgisse contemporaneamente na iconografia. Fator mais decisivo foram as Cruzadas, expressão da redescoberta da humanidade de Cristo e assim também da divindade de Adão, o único homem além de Cristo que descende diretamente de Deus (DANTE ALIGHIERI, 1979, Paradiso XIII, 86-87).

A cena de Adão sendo resgatado pelo sangue do Crucificado que cai sobre ele, era bastante popular. Um conhecido exemplo, de meados do século XI, é o crucifixo de marfim do rei Fernando I, atualmente no Museu Arqueológico de Madrid (Fig.4). Imagens desse tipo foram particularmente utilizadas no esmalte decorativo dos variados objetos litúrgicos e paralitúrgicos (crucifixos, cálices, relicários, candelabros, capas de livros, placas frontais de altar etc) fabricados em Limoges. Dentre as inúmeras peças da esmaltaria limogense que tratam daquele tema, podemos lembrar como representativa do gênero a chamada Cruz de Garnerius, de fins do século XII (atualmente no Museu do Louvre). Nela, um Adão barbudo começa a sair da tumba: cabeça voltada para o alto, ele está sentado e tem as duas mãos estendidos na direção do pé esquerdo do Senhor, pronto a recolher o sangue divino.

Em suma, a extensão formal, temática, cronológica e geográfica da iconografia adâmica, revela as estruturas profundas do Ocidente cristão da Idade Média Central. Como todo mito, o de Adão era uma forma de ver o mundo, de enunciar poeticamente, metaforicamente, valores importantes para a sociedade que o adotara e adaptara. Ora, sendo a concretização visual daquele mito, a iconografia adâmica permitia de forma direta, afetiva, que o homem medieval pensasse a si próprio. A história de Adão e Eva explicava a origem do gênero humano, do casamento, da sexualidade, da família, do trabalho, da doença, da morte, da dor, da esperança. Como a percepção de todos esses fenômenos sociais, fisiológicos e psicológicos se dá de acor- 
do com as condições de cada local e de cada momento, observar as manifestações daquele mito é observar a visão que os homens medievais tinham de si mesmos.

A revalorização do mito de Adão nos séculos XIXIII estava estreitamente articulada à tomada de consciência do homem ocidental, naquele momento em que se firmavam as línguas vernáculas, o sentimento nacionalista, a auto-análise decorrente da confissão obrigatória e periódica, a identidade católica diante dos ortodoxos, hereges, judeus e muçulmanos. Nesse contexto, o Adão representado por centenas de artis-

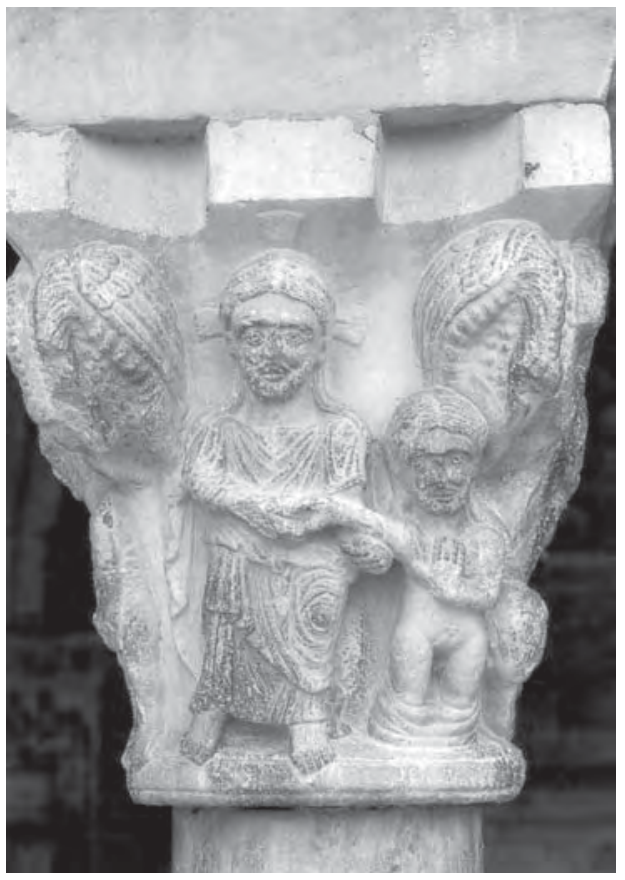

Figura 1 - Elme (foto do autor) tas e observado por milhões de pessoas, não era uma figura imutável, fixada pelos textos e pela tradição. Era a presentificação de um protótipo. Em Adão estavam contidos e prefigurados toda grandeza e toda fraqueza, todas virtudes e todos os vícios. Na sua trajetória da glória à perdição e novamente à glória, Adão sintetizava a história humana. Naquele momento em que renascia a autobiografia como gênero literário, a representação plástica de Adão e Eva, ao alcance de letrados e analfabetos, de homens e mulheres, de jovens e velhos, funcionava como uma autobiografia visual e coletiva do cristão medieval.

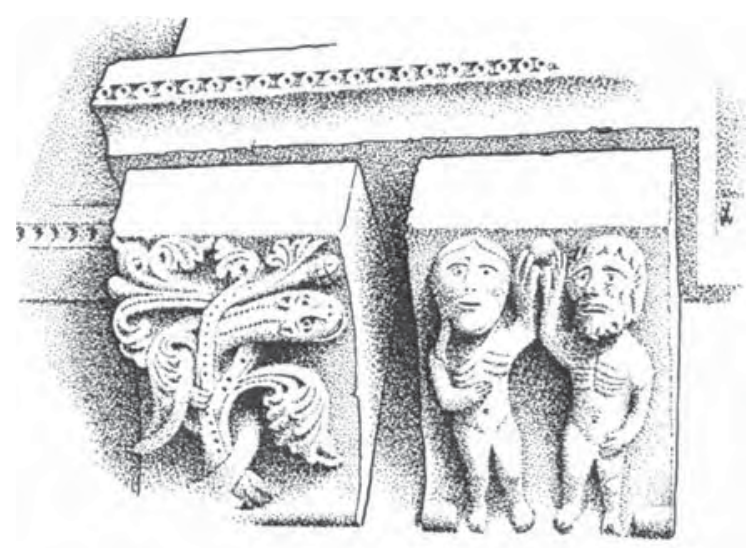

Figura 2 - Guarbecque (esboço de VERRASSEL, A. 1000 Eglises romanes de France. Paris, Duenlot, 1992, p. 697.) 


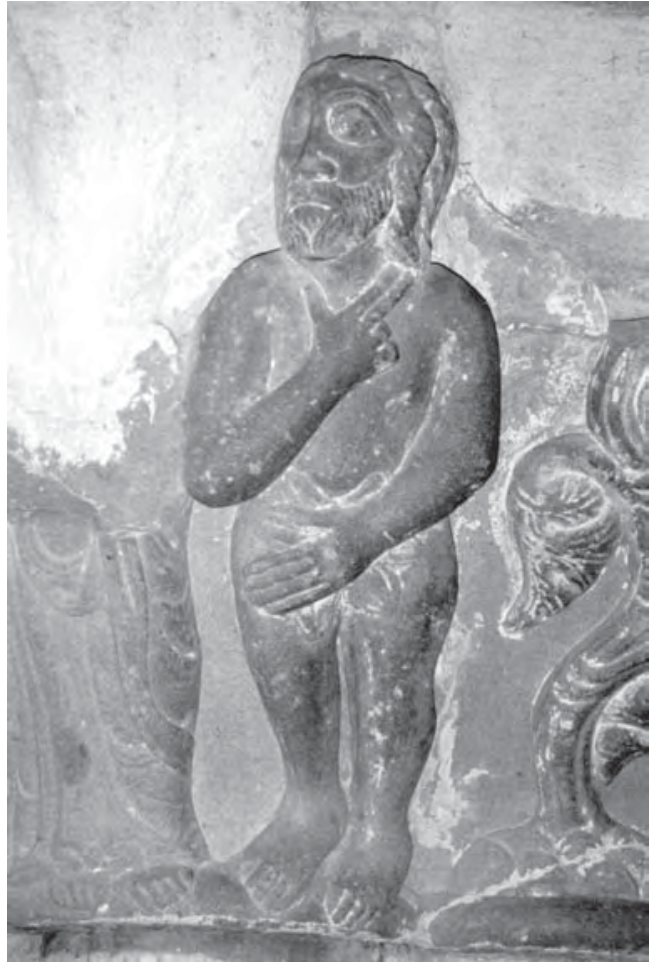

Figura 3 - San Juan de la Peña (foto do autor)

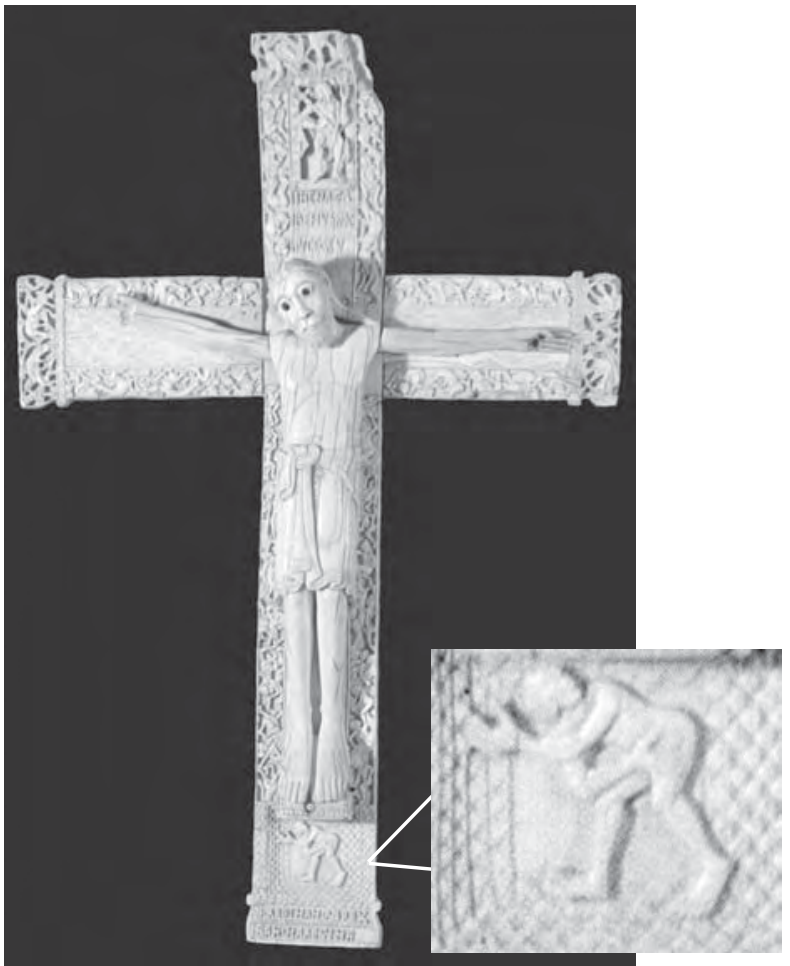

Figura 4 - Madrid (foto de E. Domínguez)

\section{Bibliografia}

a) Fontes Primárias

ANSELMO DE CANTERBURY. Cur Deus homo. ed. - trad. R. Roques, Paris, Cerf, 1963.

Beatus de Saint-Sever. Paris, Bibliothèque Nationale, ca.10281072, ms.lat.8878.

Bible de Cîteaux. Dijon, Bibliothèque Municipale, 1109, ms.14. Bible Moralisée. Paris, Bibliothèque Nationale, ca.1230-1250, ms.lat.11.560.

Biblia Pauperum. Roma, Biblioteca Vaticana, ca.1250, ms.Cod. Pal.871.

Biblia Vulgata. ed.A.Colunga e L.Turrado, Madrid, BAC, 7.ed. 1985.

DANTE ALIGHIERI. La Divina Commedia. $21^{\text {a }}$ ed.ed.G.Vandelli.

Milão, Hoepli, 1979.

Giubilei, trad.L.Fusella, em P.Sacchi (ed). Apocrifi dell' Antico Testamento. Turim, UTET, 1981, vol.I, pp.181-411.

Gli Atti di Pilato o il Vangelo di Nicodemo. trad.M.Erbetta, em Gli apocrifi del Nuovo Testamento. Casale Monferrato, Marietti, 1981, vol.II, pp.231-287.

HONORIO AUGUSTODUNENSIS, Elucidarium, em Patrologia Latina, Paris, J.-P.Migne, 1854, vol.172, col.1109-1176.

JACOPO DE VARAZZE, Legenda Aurea, vulgo historia lombardica dicta. ed.Th.Graesse, Osnabruck, Otto Zeller, reed.1969.

L'estoire del Saint Graal. ed.H.O.Sommer, Washington, Carnegie Institution, 1909. 
Los capítulos de Rabbí Eliezer. trad. M. Pérez Fernández. Valência, Institución S.Jerónimo, 1984.

PEDRO DAMIANO, Incipiunt Testimonia de Ecclesiaste, em Patrologia Latina. Paris, J.-P.Migne, 1853, vol.145, col.1139-1142.

Vita Adae. ed.J.Mozley, Journal of Theological Studies, 30, 1929, pp.121-149.

b) Fontes secundárias

ERLANDE-BRANDENBURG, A.. "L'Adam du Musée de Cluny". La Revue du Louvre et des Musées de France, 25, 1975, pp.81-90.

FRANCO JUNIOR, H. "Ave Eva! Inversão e complementaridade de um mito medieval", Revista USP, 31, 1996a, pp.52-67.

FRANCO JUNIOR, H. "A Eva barbada de Saint-Savin: imagem e folclore no século XII", em A Eva barbada. Ensaios de mitologia medieval. São Paulo, Edusp, 1996b, pp.175-198.

FRANCO JUNIOR, H. "O ouvido de Adão: escultura e mito no caminho de Santiago", em ibidem, 1996c, pp.199-217.

FRANCO JUNIOR, H. "O poder da palavra: Adão e os animais na tapeçaria de Gerona”, em ibidem, 1996d, pp.109-124.

FRANCO JUNIOR, H. As utopias medievais. São Paulo, Brasiliense, 1992.
GRIMM, R.H. Paradisus coelestis, Paradisus terrestris: Zum Auslegungsgeschichte des Paradises im Abendland bis um 1200. Munique, Fink, 1977.

HERTZ, R., "La préeminence de la main droite. Etude sur la polarité religieuse", em Sociologie religieuse et folklore. Paris, PUF, reed.1970, pp.84-109.

LLWELLYN, P. "The Names of the Roman Clergy, 401-1046". Rivista di storia della chiesa in Italia, 35, 1981, pp.355-370.

ROMANINI, A.M. (dir). Enciclopedia dell'arte medievale. Roma, Istituto della Enciclopedia Italiana, 15 vols, 1991ss (em curso).

SCHNAPPER, D. "Essai de lecture sociologique", em DUPAQUIER, J., A.BIDEAU e M.E.DUCREUX (eds.). Le prénom. Mode et histoire. Paris, EHESS, 1984.

SCHNEYER, J.B. Repertorium der Lateinischen Sermones des Mittelalters für die Zeit von 1150-1350. Munique, Aschendorffsche, vol.3, 1971.

SMEYERS, M. La miniature. Turnholt, Brepols, 1974.

WERKMEISTER, O.K.. "The Lintel Fragment Representing Eve from Saint-Lazare, Autun". Journal of Warburg and Courtauld Institutes, 35, 1972, pp.1-30.

ZAPPERI, R. L'homme enceint. trad. Paris, PUF, 1983.

Endereço do Autor: Departamento de História - FFLCH/USP • Av. Professor Lineu Prestes, 338 • CEP 05508-900 -São Paulo • SP • Brasil 